\title{
Układ hamulca elektropneumatycznego zgodny z dyrektywami TSI
}

\begin{abstract}
Dyrektywy Transportowego Systemu Transoperacyjności sporzadzone przez Parlament Europejski sq aktami prawnymi nadajacymi kierunek projektowania elektropneumatycznych układów hamulcowych pojazdów dużych prędkości ( powyżej $250 \mathrm{~km} / \mathrm{h}$ ). W artykule przedstawiono unifikacje uktadów hamulcowych zaproponowana podczas projektu MODEBRAKE.

Przedstawiono schemat uktadu hamulcowego zgodnego z Dyrektywami TSI oraz dokonano charakteryzacji jego poszczególnych części. W sktad układu hamulcowego wchodzq się dwa rodzaje modułów sterujacych: główny modut sterujacy nadzorujacy prace całego układu oraz lokalne moduly sterujace, umieszczone przy kazdej sekcji hamujacej, spetniajace rolę zespołów zaworów rozrzqdczych w pneumatycznych układach hamulcowych. W dalszej części opisano funkcje wykonawcze głównego modulu sterujacego oraz modulów lokalnych. Zostaty przedstawione możliwe tryby działania układu. Zwrócono uwage na charakterystyczne rozwiazanie dla elektropneumatycznych uktadów hamulcowych, jakim jest pętla bezpieczeństwa. Opracowano możliwe scenariusze nieprawidlowego działania układu hamulcowego, oraz przedstawiono rozwiqzania gwarantujace niezawodność pracy. Zaproponowano także wspótdziałanie z Europejskim Systemem Zarzadzania Ruchem Kolejowym oraz zachowanie taczności z Lokalnymi Centrami Sterowani Ruchem Kolejowym za pomoca systemu GSM-R na liniach nie objętych systemem ERTMS. Zaproponowano również rozwiqzania tarcz oraz okładzin ciernych hamulców tarczowych.
\end{abstract}

\section{Wstęp}

Pod koniec ubiegłego wieku na torach w Europie pojawiło się bardzo wielu producentów taboru kolejowego, którzy stosowali w swoich pojazdach różne rozwiązania budowy i sterowania układów hamulcowych. W czasach, gdy zaczęto rozmawiać o systemie transoperacyjności transportu kolejowego w Unii Europejskiej różne rozwiązania stanowiły barierę dla jego rozwoju.

W 2009 roku w ramach projektu MODBRAKE dokonano unifikacji typów układów hamulcowych, wprowadzono podział [5]:

- typ zgodny z Kartami UIC oraz normami TSI (UIC and TSI compliant);

- kompatybilny z przedstawionym w Kartach UIC, zgodny $\mathrm{z}$ normami TSI (UIC compatible, TSI compliant)

- zgodny z systemem normowanym w ramach TSI (TSI compliant).

Normy TSI są obecnie najnowszym przyszłym uregulowaniem prawnym charakteryzującym układ hamulców elektropneumatycznych. Opisane są w nich wymagania funkcjonalne, mechaniczne, elektryczne oraz pneumatyczne połączeń modułowych zgodnych z architekturą TSI. Zgodnie $\mathrm{z}$ decyzją Komisji Europejskiej z dnia 21 lutego 2008 roku, architektura TSI może być wykorzystywana do budowy pojazdów szynowych dużych prędkości (powyżej $250 \mathrm{~km} / \mathrm{h}$ ).

\section{Architektura układu}

Architekturę układu hamulcowego można podzielić na dwa moduły: moduł Sterujący Hamulcem (Brake Command Module) oraz Lokalny Moduł Sterujący (Local Brake Control Module).

Dodatkowo można wyróżnić cztery rodzaje połączeń pomiędzy tymi modułami służącymi przesyłaniu sygnałów sterujących oraz monitorujących bieżąca pracę układu:

- Przewód główny (Main pipe).

- Elektryczny przewód sterujący (Brake demand).

- Przewód zabezpieczający (Safety loop).

- Przewód zasilający (Brake pipe)

Przewód główny służy do transportu powietrza niezbędnego do prawidłowego działania urządzeń wykonawczych układu hamulcowego. Elektryczny 
przewód sterujący służy do przesyłania sygnału pochodzącego od manipulatora maszynisty, następnie sygnał przetwarzany jest w module sterującym, który przesyła sygnał do lokalnych modułów sterujących. Zatem elektryczny przewód sterujący poprowadzony jest wzdłuż całego składu pociagu i służy nie tylko przesyłaniu sygnału rozpoczynającego hamowanie, lecz również może posłużyć do bieżącej diagnostyki układu. Przewód zabezpieczający, zwany również pętlą bezpieczeństwa odpowiada za możliwość sterowania układem hamulcowym w przypadku uszkodzenia głównego przewodu elektrycznego. Kolejną jego funkcją jest możliwość wstrzymania procesu awaryjnego hamowania. W przypadku gdy dojdzie do uruchomienia hamulca bezpieczeństwa w składzie pociągu rozpoczyna się hamowanie nagłe, jednak maszynista widząc możliwe zagrożenie $\mathrm{w}$ wyniku zatrzymania się składu w niebezpiecznym miejscu, takim jak np. most, wiadukt, tunel może doprowadzić do wstrzymania procesu hamowania i doprowadzenia do zatrzymania się składu pociągu w bezpiecznym miejscu. Przewód zasilający w normalnej pracy będzie nieaktywny. Jego zadaniem jest przesyłanie sygnału pneumatycznego hamowania w przypadku, gdy skład będzie ciągniony lub ciagnący przez pojazd $\mathrm{z}$ innym systemem sterowania hamulcem.
W przypadku pracy hamulca $\mathrm{w}$ trybie normalnym, roboczym wszystkie elementy układu są w pełni sprawne i dostępne. Przewód hamulcowym poza przewodem głównym, jest pusty, a przesyłanie sygnału sterującego odbywa się drogą elektroniczną. Lokalny moduł sterujący jest sterowany sygnałem elektrycznym, który zamienia sygnał elektryczny na sygnał pneumatyczny uruchamiając $w$ ten sposób proces hamowania. Pętla bezpieczeństwa może być przez cały czas zasilana, jak również przełączona $\mathrm{w}$ tryb gotowości.

Z bardzo wielu powodów może dojść do sytuacji, gdy pojazd będzie musiał być ciagniony przez inny pojazd. W takiej sytuacji przesył sygnału hamulcowego odbywa się droga pneumatyczną. Praca lokalnych modułów hamujących opiera się na działaniu mechanicznych zaworów rozrządczych, czyli na zasadzie różnicy ciśnienia w przewodzie głównym a ciśnieniem w zbiorniku pomocniczym. Poprawne działanie pętli bezpieczeństwa oraz lokalnych modułów sterujących zapewnione jest przez energię pochodzącą $\mathrm{z}$ akumulatorów. Informacja o tym, iż skład pociągu jest ciągniony przekazywana jest kablem elektrycznym pomiędzy dwoma pojazdami.

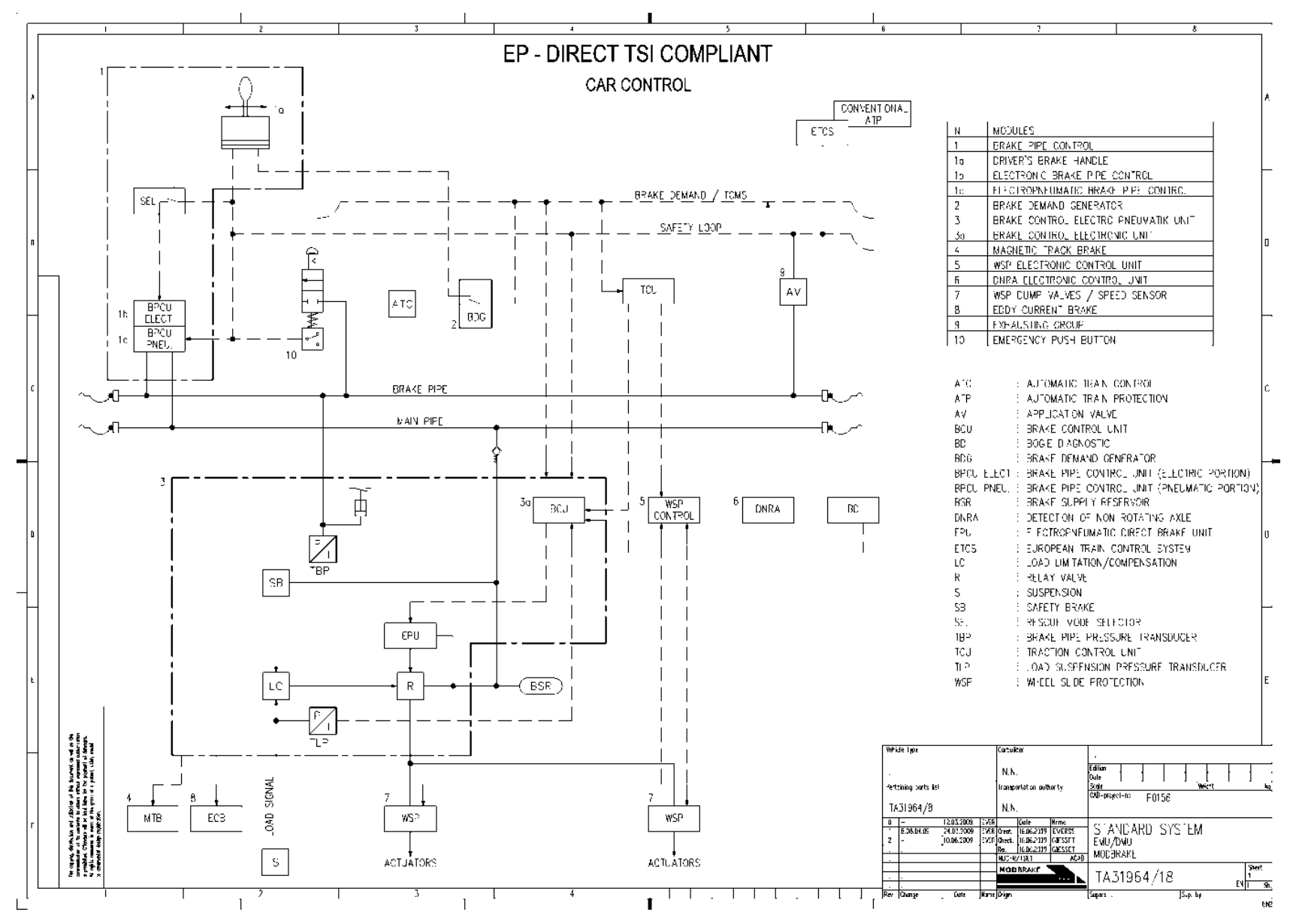

Rys.1. Schemat układu hamulcowego wg TSI [12] 
Istnieje również możliwość pracy układu w pozycji, gdy skład pociągu będzie składem ciągnącym. W takim przypadku główny przewód hamulcowy będzie napełniony powietrzem, jednak przesył sygnału hamulcowego będzie się odbywał w dwojaki sposób: pneumatycznie i elektronicznie. Różnicą ciśnień w głównym przewodzie hamulcowym regulować będzie Główny Moduł Sterujący, jednak Lokalne Moduły Sterujące nadal będą sterowane elektronicznie.

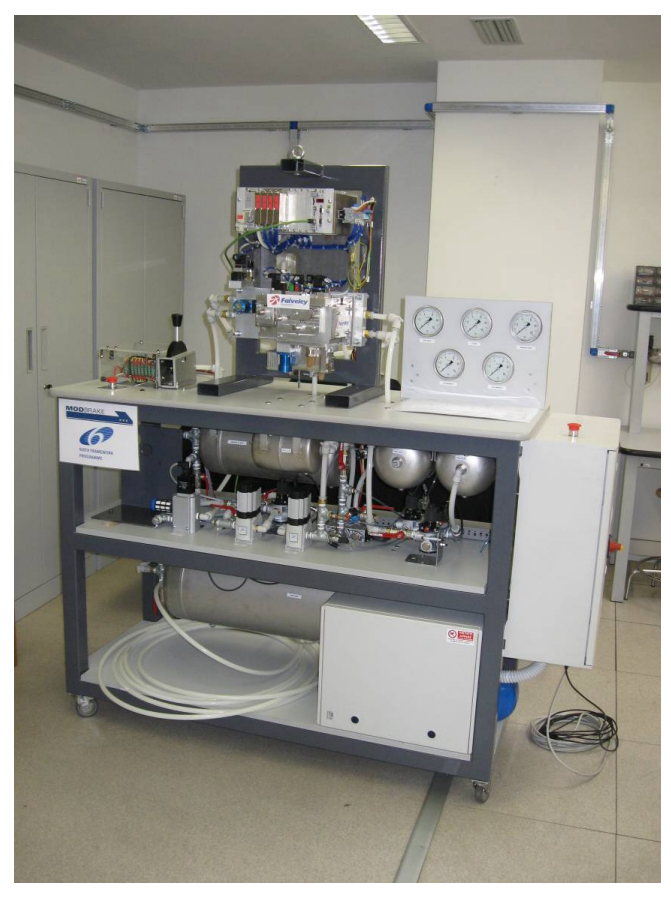

Rys.2. Model głównego modułu sterującego podczas prezentacji na konferencji MODEBRAKE na Politechnice w Turynie [14]

\section{Działanie układu}

3.1 Praca układu w trypie Normalnym.

W normalnym trybie pracy działanie układy jest zachowane poprzez Główny Moduł Sterujący wszystkie sygnały sterujące przekazywane są przez Główny Moduł Sterujący, który:

- Odbiera sygnał z hamulcowej dźwigni sterującej maszynisty lub innego urządzenia znajdującego się na pokładzie pojazdu szynowego i wysyła sygnał żądania do Lokalnych Modułów Sterujących wzdłuż całego pociagu.

- Przerywa pętlę bezpieczeństwa w przypadku wysłania sygnału od dźwigni hamulca awaryjnego.

- Zachowuje komunikację urządzeń odpowiedzialnych za monitorowanie biegu pociagu, np. urządzeń przeciwpoślizgowych.

- Przekazuje bieżące informacje, np. diagnostyczne, do komputera pociagu.

W przypadku, gdy pojazd jest pojazdem holującym sterowanie układu odbywa się tak samo jak w normalnym trybie pracy. W przypadku dezaktywacji normalnego trybu sterowanie Lokalnymi Modułami Sterującymi odbywa się przy pomocy sygnałów wysyłanych droga pneumatyczną $\mathrm{w}$ głównym przewodzie hamulcowym.

W sytuacji pojazdu ciagnionego działanie odbywa się podobnie jak w przypadku normalnego trybu pracy. Główny Moduł Sterujący czuwa nad prawidłowością przekazywania sygnału sterującego hamulcami pneumatycznymi w przewodzie głównym. Kolejna czynnością jest odpowietrzenie całego układu pneumatycznego hamulca przed rozpoczęciem procesu holowania.

Lokalny moduł sterowania hamulcem

3.2Wymagania ogólne:

- W przypadku opróżnienia przewodu głównego hamulca, moduł spowoduje zadziałanie hamulca uruchomienie tłoka.

- Informowanie, prowadzenie monitoringu nad sprawnym działaniem urządzeń biorących udział w procesie hamowania umieszczonych na danej jednostce, wagonie takie jak np.: elektrycznie sterowany zawór rozrządczy, oraz przesyłanie tych informacji do jednostki sterującej procesem hamowania.

\subsection{Wymagania funkcjonalne podczas normalnej pracy \\ Wymagania funkcjonalne podczas normalnej pracy są nastepujące:}

- Przekazanie sygnału sterującego podawanego przez przewód główny za pomocą powietrza do dalszych urządzeń wykonawczych (np. cylinder hamulcowy) oraz zbieranie dodatkowych informacji o stanie pociagu/wagonu/zestawu trakcyjnego np. aktualna prędkość, rzeczywista masa, przekazuje sygnał zwrotny o prawidłowości procesu hamowania.

- Uruchomienie cylindrów hamulcowych w przypadku, gdy dojdzie do przerwania sygnału sterującego w przewodzie głównym (dojdzie do opróżnienia).

- Zamianę sygnału elektrycznego podanego przez przewód elektryczny na sygnał wykonawczy - uruchomienie lub zaprzestanie hamowania.

- Monitorować, utrzymywać ciagłe połączenie pomiędzy wszystkimi urządzeniami sterowniczymi lub monitorującymi, a jednostką sterującą.

W przypadku gdy pojazd jest ciągnięty, holowany moduł sterowania hamulcem powinien posiadać takie same funkcje.

$\mathrm{Za}$ proces hamowania (uzupełnienie przewodu głównego, przesył sygnału sterującego itp.) odpowiedzialny jest pojazd prowadzący.

W przypadku, gdy pojazd, który holuje, ciagnie inny skład moduł powinien posiadać wszystkie opisane funkcje.

Ciśnienia pracy przy normalnej pracy modułu sterującego: 
- Maksymalne ciśnienie robocze dla cylindra hamulcowego: 6 bar

- Tolerancja: \pm 2 bary

- Histereza: 0,2 bara

- Powtarzalność: 0,2 bara

- Od 5 do 8 stopni hamowania powinien posiadać cylinder hamulcowy.

\section{Pętla bezpieczeństwa}

Pętla bezpieczeństwa jest rozwiązaniem, które nie pojawiało się we wcześniejszych pneumatycznych układach hamulcowych, za to jest specyficzna dla układów elektronicznych. W układzie hamulcowym zgodnym z TSI pętla bezpieczeństwa (safety loop) jest zbudowana $\mathrm{z}$ dwóch głównych elementów:

- generatora sygnału,

- odbiornika, dystrybutora sygnału.

Pętla bezpieczeństwa wzbudzana jest przez generator sygnału. System dystrybucji sygnału ma za zadanie kontrolowanie, monitorowanie wysłanego sygnału pochodzacego z czoła pociągu (aktywnej kabiny maszynisty) do końca pociagu oraz $\mathrm{w}$ drodze powrotnej z końca pociagu do jego czoła. W trakcie przesyłu sygnału od strony czoła pociągu (jego aktywnej kabiny sterującej) do jego końca urządzenia umieszczone na pokładzie pociągu mogą doprowadzić do jego przerwania poprzez wysłanie sygnału $\mathrm{z}$ hamulca bezpieczeństwa. W drodze powrotnej (od końca do czoła pociągu) sygnał pochodzący $\mathrm{z}$ pętli bezpieczeństwa będzie przechodził przez każdy lokalny moduł sterujący powodując jego zasilenie. Odbiornik sygnału z pętli bezpieczeństwa musi być skonfigurowany do współdziałania wspólnie z tylko z aktywną kabiną sterującą.

Projektowanie pętli bezpieczeństwa powinno odbywać się w myśl zasady „de-energize to apply”, czyli $\mathrm{w}$ wolnym thumaczeniu pozbawienie energii $\mathrm{w}$ celu zadziałania. Zasada ta polega na dodatkowym przesyłaniu sygnału energii elektrycznej pochodzącego z generatora sygnału do poszczególnych modułów sterujących. Każdy z lokalnych modułów sterujących powinien pobrać część dostarczonej energii pochodzącej z generatora sygnału dostarczanej do urządzeń bezpieczeństwa. W przypadku, gdy energia elektryczna nie zostanie „skonsumowana” przez lokalny moduł sterujący i przy odpowiednim napięciu oraz natężeniu zostanie przekazana do urządzeń bezpieczeństwa zostanie wprowadzona procedura hamowania awaryjnego w całym układzie hamulcowym, niezależnie od innych lokalnych modułów sterujących.

Pętla bezpieczeństwa powinna składać się z dwóch przewodów elektrycznych. Zasilanie pętli bezpieczeństwa powinno odbywać się prądem o napięciu zmiennym, jednak nie większej różnicy jak 5\% wartości dedykowanej dla generatora sygnału. Zakłada się również, iż w przypadku dystrybutora energii różnica nie powinna przekroczyć $30 \%$ wartości.
Następnym założeniem w konstrukcji pętli bezpieczeństwa jest wymóg oddzielenia zasilania pętli od zasilania akumulatorowego. Celem takiego rozwiązania jest uniknięcie sytuacji, gdy dojdzie to większej różnicy wartości napięcia lub też chwilowego przerwania zasilania energią, w której zostanie uruchomiona procedura hamowania awaryjnego. W przypad$\mathrm{ku}$ zasilania akumulatorowego prawdopodobieństwo zakłócenia zasilania jest znacznie większe, niż w przypadku zasilania pochodzącego bezpośrednio $\mathrm{z}$ przetwornika energii elektrycznej pochodzącej z sieci.

Pętla bezpieczeństwa może występować pojedynczo lub podwójnie. Bez wątpienia podwójna pętla bezpieczeństwa jest wariantem, który przyczyni się do większej niezawodności działania układu np. przerwanie pętli zostanie odebrane jako rozkaz do rozpoczęcia hamowania awaryjnego.

Kolejną, wartą podkreślenia właściwością pętli bezpieczeństwa jest redundancja sygnału. Atrybut ten pozwala zwielokrotnić bezpieczeństwo prawidłowego działania układów poprzez powtarzalność wysyłanego sygnału. Jest to cecha pozwalająca utwierdzić przekonanie, iż układ hamulcowy z wykorzystaniem redundancji jest układem o najwyższym poziomie bezpieczeństwa.

Układ hamulcowy zgodny z Normami TSI jest układem, w którym brane jest pod uwagę wiele scenariuszy mogących spowodować nieprawidłowe działanie układu. Jednym z powodów prowadzący do niepoprawnego funkcjonowania jest możliwość częściowego zablokowania przewodu zasilającego spowodowanego np. poprzez nieumyślne zakręcenie zaworu. W tym przypadku dojdzie do sytuacji, gdy tylko część składu pociagu będzie zasilana powietrzem z przewodu zasilającego. W sytuacji, gdy dojdzie do częściowego zablokowania przepływu powietrza w przewodzie zasilającym w czasie normalnej pracy hamulca np. w czasie jazdy, system czujników umieszczonych przy każdym lokalnym module sterującym wskaże dokładne miejsca w których nastapił spadek ciśnienia wykraczający poza dopuszczalne granice. Jeśli spadek ciśnienia okaże się bardzo gwałtowny nastapi przesłanie informacji do głównego modułu sterującego oraz na ekran pulpitu maszynisty. Główny moduł sterujący po odebraniu sygnału wskazującego spadek ciśnienia w części przewodu zasilającego doprowadzi do rozpoczęcia procesu hamowania awaryjnego. Dodatkowo informacja zostanie przekazana nie tylko do maszynisty, jak również przy wykorzystaniu kolejowych systemów łączności do najbliższych jednostek sterujących ruchem kolejowym. Warto wspomnieć, iż do przekazywania tego typu informacji można wykorzystać Europejski System Zarząadzania Ruchem Kolejowym (ERTMS).

Hamulec zaprojektowany zgodnie z Normami TSI jest hamulcem ciernym, w obecnym czasie 
zaproponowano wykorzystanie tarcz aluminiowych z dodatkiem ceramiki. Dzięki swoim właściwościom: małej wadze, dużej przewodności i pojemności cieplnej, długiej żywotności (między innymi dzięki dodatkowi ceramiki) doskonale nadają się do pojazdów dużych prędkości. Potwierdzeniem tej teorii może być fakt, iż od wielu lat znajdują swoje wykorzystaniu w niemieckich pociagach dużych prędkości ICE.

Sterowanie hamulcem odbywa się stopniowo. Poza nagłym napełnianiem, hamowaniem oraz luzowaniem układu hamulcowego sterowanie składa się na kilkanaście stopni siły hamowania, dzięki czemu sam proces hamowania jest płynniejszy oraz pozwala to maszyniście na dopasowanie stopnia hamowania do aktualnej sytuacji na torach, co bezpośrednio się przekłada na dokładność sterowania hamulcem.

Do każdego lokalnego modułu sterującego podłączone zostaną czujniki mierzące aktualny nacisk osi na tor. Taki monitoring masy pojazdu pozwoli oszacować potrzebną siłę hamująca, jak również odciąży maszynistę pojazdu od dopasowywania siły hamującej do zmieniającej się masy pojazdu. Dodatkową funkcją jest możliwość indywidualnego nastawienia siły zacisku się szczęk zaciskowych. Maszynista będzie mógł wybierać spośród kilku pozycji i dobierać ustawienia hamowania ze względu np. na profil linii kolejowej czy też warunków pogodowych.

Niepożądanym scenariuszem wpływającym na prawidłowe działanie układu hamulcowego jest za niskie lub za wysokie ciśnienie robocze panujące w przewodzie zasilającym w porównaniu do ciśnienia roboczego normalnej pracy. Główny moduł sterujący odpowiedzialny jest między innymi w utrzymywanie odpowiedniego ciśnienia roboczego w przewodzie zasilającym gwarantując w ten sposób niewyczerpalności układu. W przypadku, gdy ciśnienie robocze przekroczy dopuszczalną normę w trybie normalnego działania system powinien znaleźć ujście doprowadzając do zredukowania wartości ciśnienia. Czynności powinna zostać zasygnalizowania maszyniście. W przypadku, gdy ciśnienie robocze spadnie poniżej dopuszczalnego poziomu na całej długości przewodu zasilającego lub też tylko w jednej z jego części system powinien nakazać maszyniście załączenie hamowania awaryjnego, a także przekazać informację o rozpoczęciu takiego hamowania do najbliższych jednostek sterujących ruchem kolejowym. Maszynista będzie miał do dyspozycji dość krótki czas na reakcję, $\mathrm{np}$. zablokowanie funkcji hamowania w przypadku, gdy zatrzymanie składu pociagi może nieść ze sobą jakieś zagrożenie. W sytuacji, gdy maszynista nie podejmie działania, system automatycznie załączy hamowanie awaryjne oraz samoczynnie poinformuje najbliższe jednostki sterujące ruchem kolejowym, w tym również prześle informację o dokładnej pozycji składu pociagu na szlaku.
Brak zasilania energią elektryczną układu hamulcowego lub któregoś z lokalnych modułów sterujących spowoduje wszczęcie procedury awaryjnego hamowania, podobnie jak w przypadku, gdy sygnał wysłany w jedną stronę nie powróci do kabiny sterującej. Wartą odnotowania dodatkową funkcją w tej procedurze jest możliwość wstrzymania hamowania przez maszynistę lub też w przypadku, gdy maszynista nie podejmie, w krótkim czasie od wysłania sygnału o awaryjnym hamowaniu, żadnej reakcji dojdzie do samoczynnego rozpoczęcia hamowania.

Kolejną funkcją w układzie hamulcowym będzie samoistna diagnostyka układu hamulcowego w czasie normalnej jazdy pociagu. W sytuacji, gdy pociąg porusza się przez określoną ilość czasu z jednostajną prędkością, a w założonym czasie ani razu nie zostało załączone hamowanie główny moduł sterujący w pierwszym kroku wysyła impuls sprawdzający ciągłość układu hamującego. Drugim krokiem jest kolejne wysłanie sygnału elektrycznego załączającego hamowanie o najniższym stopniu siły hamowania. Maszynista prowadzący pociag jest informowany o wyniku pierwszego sprawdzenia, a następnie w odpowiednim przedziale czasowym powinien zezwolić na przeprowadzenie próbnego hamowania. W przypadku braku reakcji nastapi rozpoczęcie procesu hamowania awaryjnego. Samo hamowanie o najniższym stopniu odbywać się będzie do czasu, gdy maszynista będzie odczuwał zdecydowaną reakcję w postaci utraty prędkości jazdy. Jeśli proces hamowania nastapi poprawnie maszynista zadecyduje o jego przerwaniu oraz o powrocie składu do poprzedniej żądanej prędkości jazdy.

Podczas normalnego przejazdu pociagu z pasażerami może dojść do sytuacji załączenia hamulca awaryjnego przez któregoś z podróżnych bez wiedzy obsługi pociagu. W tej sytuacji istnieją dwa możliwe scenariusze wprowadzające hamowanie awaryjne składu pociagu. Pierwszą jest rozpoczęcie hamowania bez udziału maszynisty. Prowadzący pociag dostaje informację z którego miejsca w pociagu został nadany sygnał rozpoczynający hamowanie, następnie maszynista posiada możliwość wstrzymania tej procedury w określonym czasie od jej rozpoczęcia. Wstrzymanie hamowania jest tylko krótkotrwałym rozwiązaniem np. w sytuacji gdy maszynista widzi zagrożenie w miejscu zatrzymania pociagu może odłożyć hamowanie, jednak nie będzie miał możliwości całkowitego anulowania. Drugim, bardziej prawdopodobnym, rozwiązaniem jest po zaciągnięciu rączki hamowania awaryjnego pojawienie się informacji na pulpicie maszynisty o wysłanym sygnale. Następnie osoba prowadząca pociąg będzie miała krótki czas na zezwolenie hamowania lub też jego wstrzymanie czy też anulację, w przypadku braku reakcji po upłynięciu czasu dojdzie do rozpoczęcia hamowania awaryjnego. 


\section{Zakończenie}

Rozwiązania wyżej przedstawionych scenariuszy są cały czas rozważane, także nie podjęto jeszcze decyzji o faktycznych możliwościach wyników końcowych. Typ układu hamulcowego zgodny z TSI jest układem, który z pewnością jest podstawą do budowy pociagów dużych prędkości zgodnych z Systemem Interoperacyjności.

\section{Literatura:}

[1] Teobald Neuman: Wagony i hamulce kolejowe. Wyd. 3. Budowa $i$ eksploatacja. Warszawa: Wydaw.Komunik.i Łaczn., 1976.

[2] Kalinkowski Adam, Orlik Andrzej: Wagony kolejowe $i$ hamulce. Wyd. 2. Warszawa : Wydaw. Komunik.i Łaczn., 1985.

[3] Pawet Zalewski, Piotr Siedlecki, Arkadiusz Drewnowski: Technologia transportu kolejowego. Warszawa: Wydaw.Komunik.i Łaczn., 2004.

[4] Piechowiak T., Kaluba M.: Zadania IPS „TABOR" w projekcie MODBRAKE dla UE. Pojazdy Szynowe nr 3/2010

[5] Piechowiak T.: Hamulce pojazdów szynowych. Wydawnictwo Politechniki Poznańskiej, Poznań 2012.
[6] Dyrektywa Parlamentu Europejskiego $i$ Rady 2008/57/WE z 17 czerwca 2008 roku w sprawie interoperacyjności systemu kolei we Wspólnocie

[7] Karta UIC 540: Hamulce. Hamulce pneumatyczne dla pociagów towarowych i osobowych

[8] Karta UIC 541-1: Hamulec. Przepisy dotyczace konstrukcji różnych części hamulca

[9] Karta UIC 541-5: Hamulce. Elektropneumatyczne hamulce (ep-hamulce). Elektropneumatyczne mostkowanie hamulca bezpieczeństwa: Wyd. 5; Grudzień 2005.

[10] Modbrake Standard DEL_D4_3_FTI_WP4_4d

[11] Modbrake standards DEL_ D $\overline{4} \overline{3}_{-} F T \bar{I}+W P \overline{4} \_f f$

[12] De Maria F.: Systems requirements/specifications with standardised interfaces for interchangeability for the air supply module. Modbrake DEL_ D4_3_FTI_WP4_4h;09.07.2009r.

[13] De Maria F.: Prototypes of Brake Control Modules. DEL D6 1 FTI WP6 090717; 17.07.2009r.

[14] Pescarmona F., Martinelli M., Negro M.: Description and construction of test benches for articulated EMU and conventional architecture EMU. FP6 Project: PLT-031498; 13.12.2009r.

[15] [9] Karta UIC 541-6: Brakes - Electropneumatic brake (ep brake) and Passenger alarm signal (PAS) for vehicles used in hauled consists. Wyd. 1, Październik 2010 